University of Nebraska - Lincoln

DigitalCommons@University of Nebraska - Lincoln

Agronomy \& Horticulture -- Faculty Publications

Agronomy and Horticulture Department

2-1-1995

\title{
Ruminal Degradation of Switchgrass, Big Bluestem, and Smooth Bromegrass Leaf Proteins
}

\author{
Daren D. Redfearn \\ University of Nebraska-Lincoln, dredfearn2@unl.edu \\ Lowell E. Moser \\ University of Nebraska-Lincoln, Imoser1@unl.edu \\ Steven S. Waller \\ University of Nebraska-Lincoln, swaller1@unl.edu \\ Terry J. Klopfenstein \\ University of Nebraska-Lincoln, tklopfenstein1@unl.edu
}

Follow this and additional works at: https://digitalcommons.unl.edu/agronomyfacpub

Part of the Plant Sciences Commons

Redfearn, Daren D.; Moser, Lowell E.; Waller, Steven S.; and Klopfenstein, Terry J., "Ruminal Degradation of Switchgrass, Big Bluestem, and Smooth Bromegrass Leaf Proteins" (1995). Agronomy \& Horticulture -Faculty Publications. 48.

https://digitalcommons.unl.edu/agronomyfacpub/48

This Article is brought to you for free and open access by the Agronomy and Horticulture Department at DigitalCommons@University of Nebraska - Lincoln. It has been accepted for inclusion in Agronomy \& Horticulture -Faculty Publications by an authorized administrator of DigitalCommons@University of Nebraska - Lincoln. 


\title{
Ruminal Degradation of Switchgrass, Big Bluestem, and Smooth Bromegrass Leaf Proteins ${ }^{1,2}$
}

\author{
Daren D. Redfearn*, Lowell E. Moser*,3, Steven S. Waller*, \\ and Terry J. Klopfenstein ${ }^{\dagger}$
}

Departments of *Agronomy and Animal Science, University of Nebraska, Lincoln 68583-0915

\begin{abstract}
Two in situ protein disappearance experiments were conducted to determine disappearance rates of leaf protein fractions and characterize individual leaf protein fractions that escaped ruminal degradation. Fresh leaf blades of two warm-season grasses, switchgrass (Panicum virgatum L.) and big bluestem (Andropogon gerardii Vitman), and one cool-season grass, smooth bromegrass (Bromus inermis Leyss.), were included in Exp. 1. Only warmseason grasses were used in Exp. 2. Leaves were harvested from greenhouse-grown plants, placed in polyester bags, and incubated up to $48 \mathrm{~h}$ in situ in three ruminally fistulated steers fed diets of warmseason grass hay. The rate of protein disappearance for switchgrass $\left(.037 \mathrm{~h}^{-1}\right)$ was slower $(P<.10)$ than that for big bluestem $\left(.110 \mathrm{~h}^{-1}\right)$. Big bluestem and

smooth bromegrass $\left(.169 \mathrm{~h}^{-1}\right)$ disappeared at similar rates, whereas switchgrass disappeared more slowly $(P<.05)$ than smooth bromegrass in Exp. 1. Rates of protein disappearance in Exp. 2 were similar for switchgrass $\left(.112 \mathrm{~h}^{-1}\right)$ and big bluestem $\left(.116 \mathrm{~h}^{-1}\right)$. Major protein fractions that resisted ruminal degradation in both experiments, detected using SDS-PAGE, were at approximate molecular weights of 56,26 , and $24 \mathrm{kDa}$. For switchgrass and big bluestem, total protein and individual protein fractions were generally at higher concentrations and present for longer periods of time than for smooth bromegrass. This suggests that a mechanism may exist in $\mathrm{C}_{4}$ species that allows certain protein fractions to remain undegraded for longer periods compared with smooth bromegrass.
\end{abstract}

Key Words: Andropogon gerardii, Bromus inermis, Panicum virgatum, Bundle Sheath Cells, Protein Digestion, Forage

J. Anim. Sci. 1995. 73:598-605

\section{Introduction}

Ruminally degraded protein in excess of microbial requirements results in nitrogen $(\mathrm{N})$ loss as ammonia (Mathison and Milligan, 1971) and inefficient $N$ utilization by ruminants (Storm et al., 1983). Warmseason $\left(\mathrm{C}_{4}\right)$ grasses tend to be more slowly degraded in the rumen than cool-season $\left(\mathrm{C}_{3}\right)$ grasses (Minson and McLeod, 1970; Van Soest, 1982). Akin and Burdick (1975) concluded that digestibility differences between $\mathrm{C}_{3}$ and $\mathrm{C}_{4}$ grasses were associated with parenchyma bundle sheath cells of $\mathrm{C}_{4}$ grasses. Animal

\footnotetext{
${ }^{1}$ Contribution from the Nebraska Agric. Exp. Sta. Journal series no. 10753.

${ }^{2}$ Mention of a trade name or a specific product does not constitute a guarantee of the product by the University of Nebraska and does not imply its approval to the exclusion of other suitable products.

${ }^{3}$ To whom correspondence should be addressed

Received June 2, 1994.

Accepted October 6, 1994.
}

performance on warm-season grasses is often greater than expected based on available forage quality.

Protein not ruminally degraded allows more amino acids to reach the small intestine (Chalupa, 1975). Animals grazing cool-season grasses supplemented with ruminally undegradable protein sources had increased weight gains (Anderson et al., 1988; Blasi et al., 1991). Likewise, lack of responses to supplementation of ruminally undegradable proteins by animals grazing warm-season grasses has been verified (Blasi et al., 1991; Hafley et al., 1993). Minimal information exists regarding utilization of individual protein fractions in forages, particularly warm-season grasses. The objectives of this research were to determine rates of disappearance for leaf protein in switchgrass ( Panicum virgatum L.), big bluestem (Andropogon gerardii Vitman) $\left(\mathrm{C}_{4}\right.$ ), and smooth bromegrass (Bromus inermis Leyss.) $\left(\mathrm{C}_{3}\right)$. Additionally, ruminally degraded protein fractions were characterized and compared with ruminally undegraded protein fractions. 


\section{Materials and Methods}

Experiment 1. Randomly selected leaves of switchgrass, big bluestem, and smooth bromegrass tillers were harvested from greenhouse-grown plants. Management of these plants resulted in disease-free, vigorous plants morphologically similar to field-grown plants. Switchgrass and smooth bromegrass were in the late vegetative stage $\left(\mathbf{V}_{\mathbf{4}}\right)$ and big bluestem was in the late elongation stage ( $\mathbf{E}_{\mathbf{4}}$ ) (Moore et al., 1991). Fully expanded leaf blades were cut horizontally into 5 -mm sections using a single-edged razor blade. Masticated forage would undoubtedly result in additional disruption of the barriers to protein degradation. Samples $(1 \mathrm{~g})$ of fresh leaf blade sections were placed in small polyester bags $(5 \mathrm{~cm} \times 10 \mathrm{~cm}$; pore size $=53 \pm 10 \mu \mathrm{m})$ that had been heat-sealed on three sides (Ankom, Fairport, NY). Samples $(.35 \mathrm{~g})$ of cotton fiber treated with $1 N$ sodium hydroxide $(\mathrm{NaOH})$ for $24 \mathrm{~h}$ were placed in small polyester bags. These samples were included to estimate the molecular weights ( MW) of associated microbial proteins. All polyester bags were enclosed in a nylon, zippered mesh bag $(32 \mathrm{~cm} \times 53 \mathrm{~cm})$ and placed into the ventral sac of three ruminally fistulated steers fed diets of warm-season grass hay including switchgrass and big bluestem. The experiments were blocked on animal.

Samples were incubated for $4,8,16,24$, or $48 \mathrm{~h}$. A leaf blade sample of each forage species and an undigested $\mathrm{NaOH}$-treated cotton fiber sample were not incubated to represent undigested material $(0 \mathrm{~h})$. After each incubation period, one small polyester bag of each forage and one bag of cotton fiber were removed randomly from the mesh bag and washed (Wilkerson et al., 1990).

Digested samples were removed from the polyester bags and ground with a mortar and pestle in $12 \mathrm{~mL}$ of $.06 M$ Tris-HCl (Tris[hydroxymethyl] aminomethane)-hydrochloric acid protein extraction buffer $(\mathrm{pH}$ 8.8 ) with $2 \%$ (wt/vol) sodium dodecyl sulfate (SDS), $.06 \mathrm{M}$ glycerol, and $.002 \mathrm{M}$ ethylenediamine tetraacetate. Approximately $.5 \mathrm{~g}$ of acid-washed sea sand was added as an abrasive. The samples were macerated until no discernable leaf tissue remained. Confirmation of bundle sheath cell rupture was monitored with a dissecting microscope by observation of the release of the chloroplasts located in the bundle sheath cells. The undigested tissue was prepared in the same manner. The macerated tissue was centrifuged at $2,350 \times g$ for $10 \mathrm{~min}$ to separate the sand and plant fibers from the supernatant. Aliquots of the supernatant were used for protein analysis and SDS-PAGE procedures. Degree of protein extractions for undigested $\mathrm{C}_{4}$ and $\mathrm{C}_{3}$ grasses ranged from 70 to $105 \%$ when compared with Kjeldahl N (AOAC, 1990). The $\mathrm{C}_{4}$ grasses tended to have a lower degree of extractable protein than the $\mathrm{C}_{3}$ species. This may be attributed to the protein localized in the bundle sheath cells.
Experiment 2. The use of $\mathrm{NaOH}-$ treated cotton fiber was not a valid measure of microbial protein. The protein analysis of the treated cotton fiber in Exp. 1 indicated only a very small protein concentration associated with the $\mathrm{NaOH}$-treated cotton fiber. Microbial attachment was not sufficient to determine protein fractions using the described protein assay or SDS-PAGE, so $\mathrm{NaOH}$-treated cotton fiber was not included in Exp. 2. Protein associated with attached ruminal microorganisms was assumed to be minimal and was not accounted for in the estimation of protein degradation rates.

Smooth bromegrass was not included in Exp. 2 due to lack of regrowth between experiments. Big bluestem was in the late vegetative stage $\left(\mathbf{V}_{\mathbf{5}}\right)$, whereas switchgrass was in the late elongation stage $\left(\mathbf{E}_{5}\right)$. Sample sizes of leaf blade sections were reduced from 1.0 to $.5 \mathrm{~g}$ because there was an abundance of protein for the SDS-PAGE procedures. Incubation periods were changed to $6,12,24,36$, and $48 \mathrm{~h}$ to obtain values for total protein and individual protein fractions of switchgrass and big bluestem that were present at $36 \mathrm{~h}$.

After random removal of the polyester bags from the mesh bag, the sample preparation was modified for Exp. 2 by placing the digested, rinsed leaf tissue from the small bags immediately into liquid $\mathrm{N}$ and grinding the frozen leaf tissue into a powder with a mortar and pestle. The frozen leaf tissue was thawed into the Tris- $\mathrm{HCl}$ protein extraction buffer. A $1 \mathrm{mM}$ phenylmethane sulfonyl fluoride solution was included in the protein extraction buffer as a serine protease inhibitor (Fahrney and Gold, 1963; Cotta and Hespell, 1986). Leaf tissue was ground and centrifuged in the same manner as in Exp. 1.

Total Protein. Protein concentration was determined using subsamples taken from the aliquots of extracted leaf protein. Protein concentration was assayed in triplicate using bicinchoninic acid (Smith et al., 1985) with bovine serum albumin (BSA) used to prepare a standard curve. Absorbance was determined with a double-beam spectrophotometer. The protein concentration of the extracted leaf protein samples was determined by plotting the corrected absorbance against the protein concentration of the BSA.

SDS-PAGE. Fifty microliters of $1.5 \mathrm{M}$ Tris-HCl buffer ( $\mathrm{pH} 8.4$ ) and $25 \mu \mathrm{L}$ of $.5 \mathrm{M}$ dithioerythritol, used to cleave disulfide bonds, was added to the leaf protein extract in a $1.5-\mathrm{mL}$ microcentrifuge tube and the tube was placed into a boiling water bath for 10 min. After boiling, $100 \mu \mathrm{L}$ of 2 -mercaptoethanol, used to maintain cleaved disulfide bridges, and $25 \mu \mathrm{L}$ of . $2 \%$ ( $\mathrm{wt} / \mathrm{vol}$ ) bromophenol blue solution, used as tracking dye, were added. The microcentrifuge tubes that contained the reduced, SDS-complexed proteins were placed on a $55^{\circ} \mathrm{C}$ heat block until protein separation.

Proteins were separated on $16-\mathrm{cm} \times 20-\mathrm{cm}$ gels using a discontinuous buffered gel system (Laemmli, 
1970) with a final acrylamide concentration of $12.5 \%$. The electrophoresis instrument was a PROTEAN II vertical slab cell unit (Bio-Rad, Richmond, CA). The protein samples were loaded in equal volumes of $30 \mu \mathrm{L}$ that gave amounts of proteins that ranged from 25.5 to $153 \mu \mathrm{g}$. Molecular weight markers ( 2.5 to $205 \mathrm{kDa}$ ) and purified samples of phosphoenolpyruvate carboxylase (PEPcase) and ribulose-1,5-bisphosphate carboxylase-oxygenase ( RUBPcase) (Sigma Chemical, St. Louis, MO) were prepared and loaded in the same manner as the protein samples of the undigested and digested leaf tissue. The electrophoresis unit was connected to a power supply operated at a constant power ( 40 watts) until the dye front reached the bottom of the gel.

Gels were stained with Coomassie blue dye and stored in $5 \%$ ( $\mathrm{vol} / \mathrm{vol}$ ) acetic acid. The Coomassie blue stain was chosen because it gives a distinct band with a small amount of protein present in the gel. Use of silver staining detected less protein, but the background stained too heavily. The major protein fractions of interest were distinguished easily using the Coomassie blue stain. Stained gels were scanned to quantify the major individual protein fractions of the total leaf protein. These were calculated as the optical density $\times$ area of the protein fractions and used to calculate the amount of protein as a percentage of all quantified protein fractions present using a Visage 110 Image Analyzer (Millipore, Ann Arbor, MI).

Statistical Analyses. Experiment 1 was conducted as a randomized complete block design with a $3 \times 6$ factorial (species $\times$ incubation period) arrangement of the treatment combinations, whereas Exp. 2 was conducted as a randomized complete block with a $2 \times 6$ (species $\times$ incubation period) factorial arrangement of the treatment combinations. The forage in the polyester bag was considered the experimental unit, with animal as the replication. Sources of variation included block, forage species, and in situ incubation period.

Experiments were analyzed separately using the GLM procedures of SAS (1985). Rates of protein degradation were calculated using the natural logarithmic transformation of the average residual protein concentration as a percentage of the protein in fresh leaf blades at $0 \mathrm{~h}$ (Waldo et al., 1972). In Exp. 1 residual protein for cool- and warm-season grasses was assumed to be ruminally nondegradable following 24 and $48 \mathrm{~h}$, respectively. Rates of protein disappearance were determined using in situ incubation periods of $0,4,8,16$, and $24 \mathrm{~h}$ for the switchgrass and big bluestem and $0,4,8$, and $16 \mathrm{~h}$ for the smooth bromegrass. For Exp. 2, residual protein at $48 \mathrm{~h}$ was assumed to be ruminally nondegradable. Rates of protein disappearance were determined using in situ incubation periods of $0,6,12,24$, and $36 \mathrm{~h}$ for the switchgrass and big bluestem. The slopes of the lines representing the protein degradation rates for the grasses were compared using paired $t$-tests (Steel and Torrie, 1980).

\section{Results}

Experiment 1. The rates of protein disappearance (Figure 1) during these time periods were fastest for smooth bromegrass $\left(.169 \mathrm{~h}^{-1}\right)$, followed by those for big bluestem $\left(.110 \mathrm{~h}^{-1}\right)$ and switchgrass $\left(.037 \mathrm{~h}^{-1}\right)$. The rates of protein disappearance were different $(P<$ .10) between switchgrass and big bluestem. Likewise, the rates of protein disappearance for switchgrass and smooth bromegrass were different $(P<.05)$. However, protein disappearance rates were not different for big bluestem and smooth bromegrass. Values for total protein and ruminally degradable and nondegradable protein fractions for switchgrass, big bluestem, and smooth bromegrass are given in Table 1.

Analysis of acrylamide gels indicated three major protein fractions with approximate molecular weights of 56,26 , and $24 \mathrm{kDa}$ (Figure 2 ). The $56-\mathrm{kDa}$ protein fraction was apparently the large subunit (LS) of the RUBPcase enzyme. In all three species, this fraction had a migration distance and banding area similar to that of the purified standard. The 26- and $24-\mathrm{kDa}$ protein fractions were not identified.

Image analysis of acrylamide gels indicated significant species $x$ incubation period differences $(P<.05)$ for concentration of the $56-\mathrm{kDa}$ protein fraction (Figure 3). The $56-\mathrm{kDa}$ protein fraction composed approximately $270 \mathrm{mg} / \mathrm{g}$ of total leaf protein in the undigested leaf tissue of smooth bromegrass, compared with 160 and $130 \mathrm{mg} / \mathrm{g}$ for switchgrass and big bluestem, respectively. The $56-\mathrm{kDa}$ protein fraction was present up to $24 \mathrm{~h}$ in switchgrass but was not observed after $16 \mathrm{~h}$ in big bluestem and $8 \mathrm{~h}$ in smooth bromegrass.

Species $\times$ incubation period differences were also evident $(P<.05)$ for the $26-\mathrm{kDa}$ protein fraction. Concentrations of the $26-\mathrm{kDa}$ protein fractions were similar for big bluestem $(330 \mathrm{mg} / \mathrm{g})$ and smooth bromegrass $(310 \mathrm{mg} / \mathrm{g})$. This fraction composed only $180 \mathrm{mg} / \mathrm{g}$ in switchgrass. This protein fraction was observed up to $24 \mathrm{~h}$ in switchgrass and big bluestem but only up to $8 \mathrm{~h}$ in smooth bromegrass. Species $\times$ incubation period interactions were different $(P<.10)$ for the disappearance of the $24-\mathrm{kDa}$ protein fraction. This fraction composed approximately $180 \mathrm{mg} / \mathrm{g}$ of the total leaf protein in undigested leaf tissue of big bluestem. This fraction composed only $40 \mathrm{mg} / \mathrm{g}$ in switchgrass and $10 \mathrm{mg} / \mathrm{g}$ in smooth bromegrass and could be distinguished for $24 \mathrm{~h}$ in switchgrass but only for $8 \mathrm{~h}$ in big bluestem and for $4 \mathrm{~h}$ in smooth bromegrass.

Experiment 2. Disappearance rates for protein were not different between switchgrass $\left(.112 \mathrm{~h}^{-1}\right)$ and big bluestem $\left(.116 \mathrm{~h}^{-1}\right)$ (Figure 4). Values for total protein and ruminally degradable and nondegradable protein fractions for switchgrass and big bluestem are given in Table 2.

Analysis of acrylamide gels again indicated three major protein fractions with approximate molecular weights of 56,26 , and $24 \mathrm{kDa}$. Species $\times$ incubation 


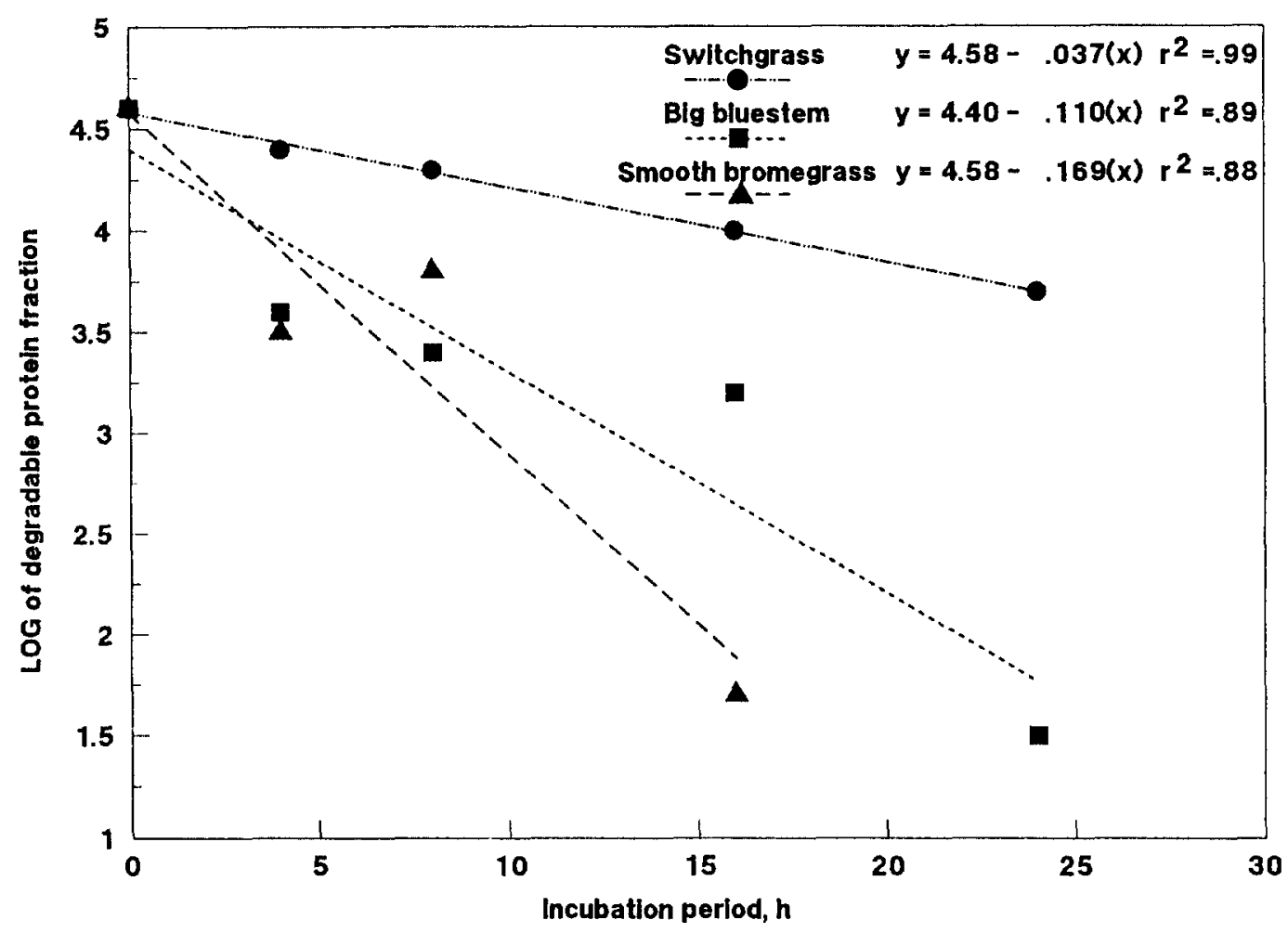

Figure 1. Total protein disappearance rates for big bluestem, switchgrass, and smooth bromegrass calculated using the natural logarithmic transformation of the average residual protein as a percentage of the digestible protein at zero hour (Exp. 1). Standard error of estimate for the regressions for switchgrass, big bluestem, and smooth bromegrass are $.06, .69$, and .43 , respectively.

period differences existed $(P<.05$ ) for the disappearance of the $56-\mathrm{kDa}$ protein fraction (Figure 5). This fraction composed approximately $200 \mathrm{mg} / \mathrm{g}$ of the total leaf protein in switchgrass, whereas this fraction composed only $70 \mathrm{mg} / \mathrm{g}$ of the total leaf protein in big bluestem. This fraction was present for $36 \mathrm{~h}$ in switchgrass and for $6 \mathrm{~h}$ in big bluestem.

Table 1. Total protein and ruminally degradable and nondegradable fractions in switchgrass, big bluestem, and smooth bromegrass leaf blades (Exp. 1)

\begin{tabular}{|c|c|c|c|}
\hline \multirow[b]{2}{*}{$\begin{array}{l}\text { Protein } \\
\text { fraction }\end{array}$} & \multicolumn{3}{|c|}{ Species } \\
\hline & Switchgrass & $\begin{array}{c}\text { Big } \\
\text { bluestem }\end{array}$ & $\begin{array}{c}\text { Smooth } \\
\text { bromegrass }\end{array}$ \\
\hline Total, mg/g DM ${ }^{a}$ & $100.6^{\mathrm{d}}$ & $226.2^{\mathrm{d}}$ & $222.3^{\mathbf{e}}$ \\
\hline Degradable, mg/g of protein ${ }^{b}$ & $847^{\mathrm{d}}$ & $795^{\mathrm{d}}$ & $974^{\mathrm{e}}$ \\
\hline $\begin{array}{l}\text { Nondegradable, } \mathrm{mg} / \mathrm{g} \\
\text { of protein }^{c}\end{array}$ & $153^{\mathrm{d}}$ & $205^{\mathrm{d}}$ & $26^{\mathrm{e}}$ \\
\hline
\end{tabular}

${ }^{a}$ Concentration of leaf protein of nondigested leaves expressed on a drv matt.er hasic
The 26-kDa protein fraction composed a larger portion of the total leaf protein in switchgrass than in big bluestem ( 230 vs $110 \mathrm{mg} / \mathrm{g}$ ). This protein was present up to $24 \mathrm{~h}$ in big bluestem but only up to $12 \mathrm{~h}$ in switchgrass, resulting in a significant species $x$ incubation period interaction $(P<.05)$. Species $x$ incubation period differences were apparent $(P<.05)$ for the 24-kDa protein fraction. This fraction composed $40 \mathrm{mg} / \mathrm{g}$ of the total in switchgrass but only $20 \mathrm{mg} / \mathrm{g}$ of the total in big bluestem. This protein fraction was distinguishable up to $12 \mathrm{~h}$ in both big bluestem and switchgrass.

\section{Discussion}

Use of a simple first-order model to describe ruminal protein degradation depends on the definition of the digestible protein fraction. This fraction was calculated by subtraction of the indigestible fraction from the total protein remaining at each fermentation time and is defined as the first-order fractional rate 


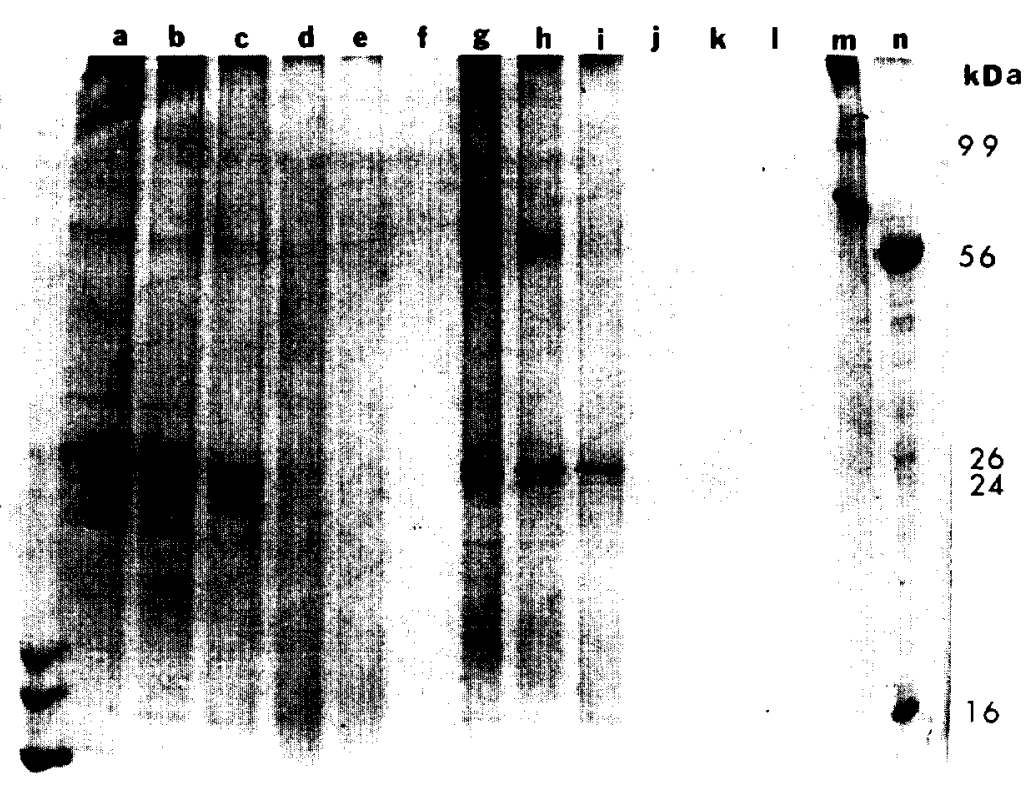

Figure 2. Banding patterns of extracted leaf proteins from switchgrass $(a-f)$ and smooth bromegrass (g-1) following $0,4,8,16,24$, or $48 \mathrm{~h}$ of in situ rumen incubation with purified PEPcase $(\mathrm{m})$ and RUBPcase (n) protein fractions.

The difference in protein disappearance rates for smooth bromegrass and switchgrass may have been a direct result of anatomical arrangement of the plant tissues (Akin and Burdick, 1975) attributed to the different photosynthetic mechanisms of $\mathrm{C}_{3}$ and $\mathrm{C}_{4}$ species. The similarity of protein disappearance rates for big bluestem and smooth bromegrass in Exp. 1 was not expected. Our value for protein disappearance rate of smooth bromegrass $\left(.169 \mathrm{~h}^{-1}\right)$ was similar to that of Anderson et al. (1988), who estimated rates of CP degradation ranging from .117 to $.14 \mathrm{~h}^{-1}$. Protein degradation rates for other cool-season grasses have been reported by Beever and Siddons (1986), who estimated CP degradation rates of .09 to $.14 \mathrm{~h}^{-1}$ for perennial ryegrass (Lolium perenne L.).

Considerably different rates of protein disappearance were observed for switchgrass between the two experiments. These differences may have been a direct result of experimental modifications, which reduced the experimental error in Exp. 2 by approximately

— $56 \mathrm{kDa} \quad \mathbb{I l} 26 \mathrm{kDa} \square 24 \mathrm{kDa}$ Other fractions

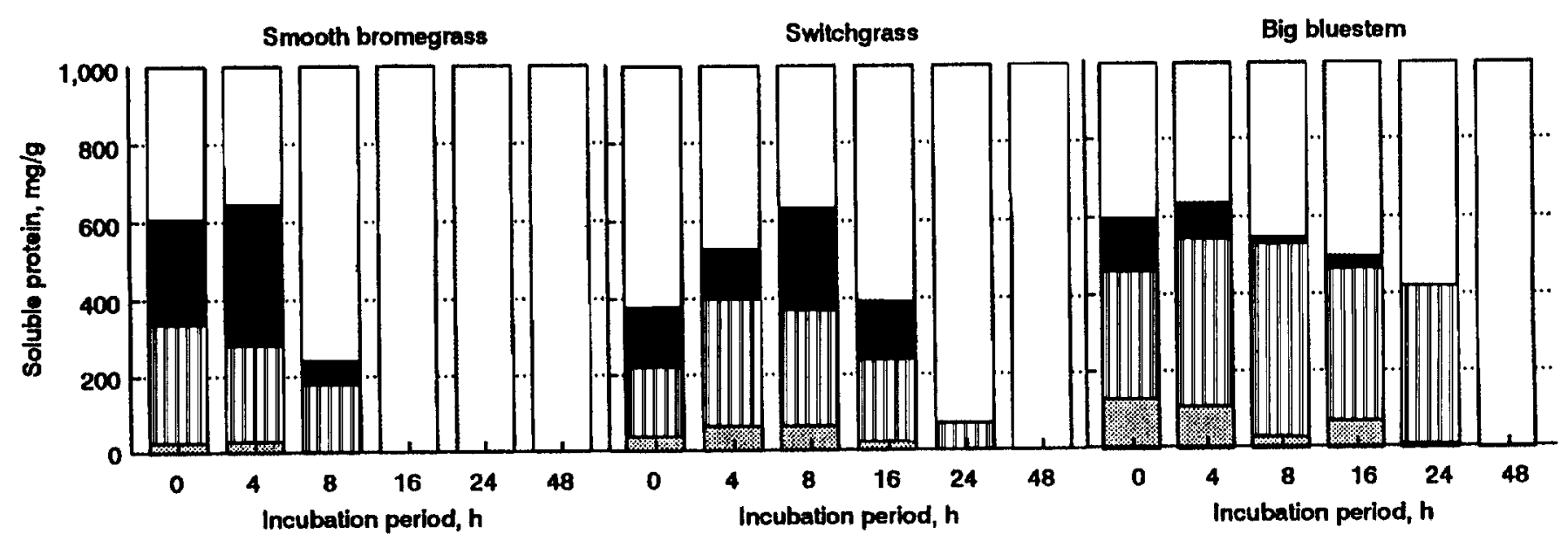

Figure 3. Composition of major protein fractions in smooth bromegrass, switchgrass, and big bluestem after 0,4 , $8,16,24$, or $48 \mathrm{~h}$ of in situ rumen incubation (Exp. 1). 


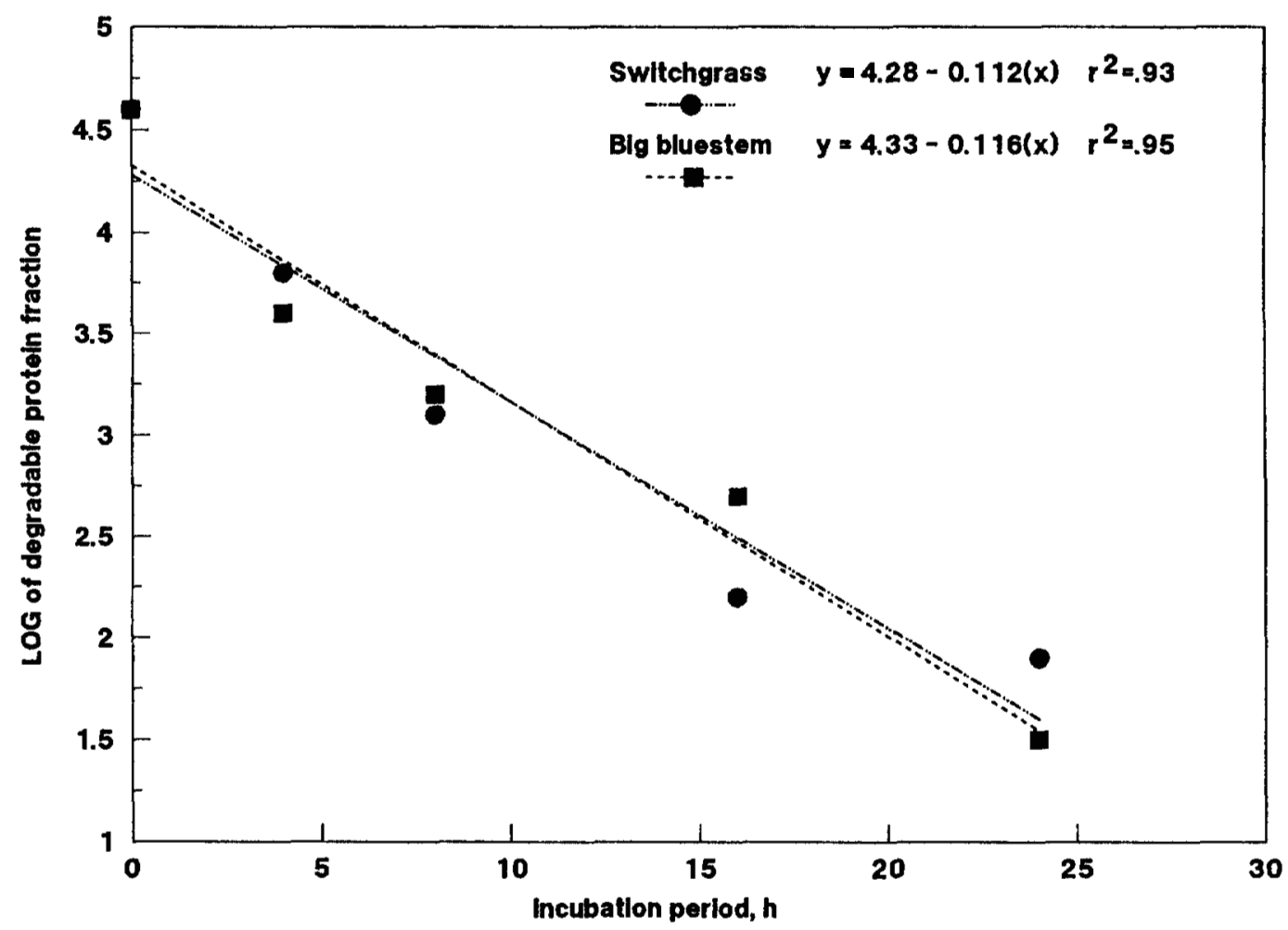

Figure 4. Total protein disappearance rates for big bluestem and switchgrass calculated using the natural logarithmic transformation of the average residual protein as a percentage of the digestible protein at zero hour (Exp. 2). Standard errors of estimate for the regressions for switchgrass and big bluestem are .33 and .32 , respectively.

one-half compared with Exp. 1. Although the arrangement of tissues in switchgrass and big bluestem were similar, differences in the rates of protein disappearance for switchgrass and big bluestem may be explained partially by leaf protein allocation differences within the mesophyll and bundle sheath cells. Leaf maturity may have accounted for some differences, although leaf blades tend to be more consistent in forage quality parameters (Griffin and Jung, 1983; Sanderson and Wedin, 1989).

Mullahey et al. (1992) concluded that switchgrass had a higher escape protein concentration $(509 \mathrm{mg} / \mathrm{g})$ than smooth bromegrass $(205 \mathrm{mg} / \mathrm{g}$ ) averaged over a range of plant maturities. In our study, the calculated values for escape protein concentration following $24 \mathrm{~h}$ in situ were 260 to $463 \mathrm{mg} / \mathrm{g}$ and 257 to $337 \mathrm{mg} / \mathrm{g}$ of the total protein for switchgrass and big bluestem, respectively. The values for big bluestem were similar to those of Blasi et al. (1991), who predicted that 220 to $300 \mathrm{mg} / \mathrm{g}$ of the total protein in big bluestem would escape ruminal degradation. These researchers suggested that the apparent increase in escape protein of warm-season grasses might have been due to protection of the RUBPcase protein molecule by the bundle sheath cell. Anderson et al. (1988) and Blasi et al. (1991) predicted that only 70 to $145 \mathrm{mg} / \mathrm{g}$ of the total protein in smooth bromegrass would escape ruminal degradation. In our studies, approximately $75 \mathrm{mg} / \mathrm{g}$ of the protein in smooth bromegrass would be available for postruminal utilization.

A compartmentalization of photosynthetic enzymes occurs in $\mathrm{C}_{4}$ species; greater than $98 \%$ of the PEPcase is located in the mesophyll cells and greater than $98 \%$ of the RUBPcase is restricted to the bundle sheath cells (Chen et al., 1973; Huber et al., 1976). Significant amounts of RUBPcase exist in both $\mathrm{C}_{3}$ and $\mathrm{C}_{4}$ species. The values for RUBPcase protein composition in undigested leaf tissue of $\mathrm{C}_{3}$ and $\mathrm{C}_{4}$ species

Table 2. Total protein and ruminally degradable and nondegradable fractions in switchgrass and big bluestem leaf blades (Exp. 2)

\begin{tabular}{|c|c|c|}
\hline \multirow[b]{2}{*}{ Protein fraction } & \multicolumn{2}{|c|}{ Species } \\
\hline & Switchgrass & Big bluestem \\
\hline Total, mg/g DMa & $191.4^{\mathrm{d}}$ & $138.4^{\mathrm{e}}$ \\
\hline Degradable, mg/g of protein ${ }^{b}$ & 887 & 806 \\
\hline Nondegradable, $\mathrm{mg} / \mathrm{g}$ of protein ${ }^{\mathrm{c}}$ & 113 & 194 \\
\hline
\end{tabular}

${ }^{a}$ Concentration of leaf protein of nondigested leaves expressed on a dry matter basis.

b Concentration of ruminally degraded leaf protein following $24 \mathrm{~h}$ in situ expressed on a total protein basis.

${ }^{c}$ Concentration of ruminally nondegraded leaf protein following $24 \mathrm{~h}$ in situ expressed on a total protein basis. $.10)$. 
Switchgrass

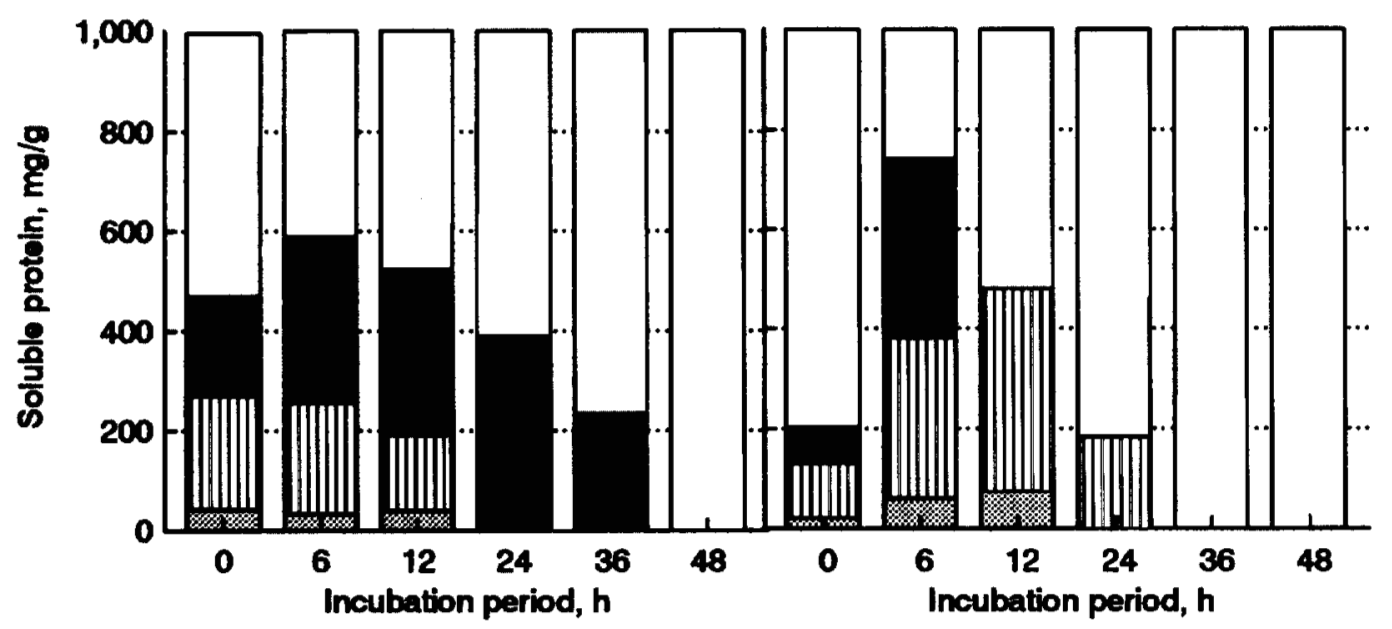

Figure 5. Protein fractions of switchgrass and big bluestem after $0,6,12,24,36$, or $48 \mathrm{~h}$ of in situ rumen incubation (Exp. 2).

were within the range given by $\mathrm{Ku}$ et al. (1979), who estimated that $\mathrm{C}_{3}$ species allocated 25 to $60 \%$ of the total protein to RUBPcase, whereas $\mathrm{C}_{4}$ species allocated 8 to $23 \%$ of RUBPcase toward the total protein. Approximately $10 \%$ of the protein fraction of $\mathrm{C}_{4}$ species may be composed of PEPcase (Uedan and Sugiyama, 1976). Thus, the loss of protein fractions from the bundle sheath cells of warm-season grasses, especially RUBPcase, could be used as an indicator of bundle sheath cell integrity (Miller et al., 1993).

In the presence of SDS, the RUBPcase protein molecule dissociates into a LS with a molecular weight of approximately $56 \mathrm{kDa}$ and a smaller subunit (SS) with an approximate molecular weight of $16 \mathrm{kDa}$ (Rutner and Lane, 1967). Present in all three species, the $56-\mathrm{kDa}$ protein fraction closely corresponded to the LS banding pattern of the purified RUBPcase protein molecule. No protein fraction was identified as the SS of the protein molecule due to an abundance of molecular weight proteins in these regions of the gels. The fraction assumed to be RUBPcase in smooth bromegrass was intermediate in time of disappearance between switchgrass and big bluestem for Exp. 1, whereas the 56-kDa protein fraction in switchgrass disappeared more slowly than big bluestem in Exp. 2 . Treatment and separation of chloroplasts by SDSPAGE yielded two chlorophyll-protein complexes ( CPI and CPII), with a single band at $70 \mathrm{kDa}$ for the CPI complex and two polypeptides of 26 and $24 \mathrm{kDa}$ for the CPII complex (Thornber et al., 1967). No major protein fractions were observed at $70 \mathrm{kDa}$, although two major protein fractions were observed at approximate molecular weights of 26 and $24 \mathrm{kDa}$.
The protein fractions associated with the CPII were more abundant than RUBPcase and seemed to remain undegraded for longer periods of time. This suggests that the CPII protein fraction in warm-season grasses may be more important than the RUBPcase in supplying escape protein to grazing ruminants. Because three protein fractions appeared identical in cool- and warm-season grasses, some mechanism in the warm-season species slowed the degradation of the proteins. With a portion of the chloroplasts located within the bundle sheath cells, the slower degradability of the bundle sheath cell wall may enhance the chance of intact chloroplasts reaching the small intestine.

Different proteins have shown different rates of ruminal degradation (Mangan, 1972; Nugent and Mangan, 1978). In $\mathrm{C}_{3}$ species, the 56-, 26-, and $24-\mathrm{kDa}$ protein fractions were located within the mesophyll chloroplasts. In $\mathrm{C}_{4}$ species, the $56-\mathrm{kDa}$ protein fraction was restricted to the chloroplasts in the more slowly degraded bundle sheath cells (Akin and Burdick, 1977), with the 26- and 24-kDa protein fractions present in both the mesophyll and bundle sheath cell chloroplasts (Salisbury and Ross, 1985). Although the identity of the major protein fractions in this study cannot be established with certainty, some protein molecules apparently escaped ruminal degradation up to $36 \mathrm{~h}$ in big bluestem and switchgrass. Increasing proportions of these protein fractions in degraded tissue of warm-season grasses strongly supports the hypothesis that a portion of proteins may be protected from ruminal degradation by the bundle sheath cells. 


\section{Implications}

Differences in the rates of ruminal protein disappearance for switchgrass, big bluestem, and smooth bromegrass suggest that generalizations regarding ruminal protein degradability should not be made among forage species. Similar protein fractions in switchgrass, big bluestem, and smooth bromegrass were ruminally degraded to different extents at identical incubation times and were apparently influenced by anatomical structures and metabolism within the plant. Influence of plant maturity on animal selection and digestion and other plant factors should also be considered when developing strategies for protein supplementation.

\section{Literature Cited}

Akin, D. E., and D. Burdick. 1975. Percentage of tissue types in tropical and temperate grass leaf blades and degradation of tissues by rumen microorganisms. Crop Sci. 15:661.

Akin, D. E., and D. Burdick. 1977. Ruminal microbial degradation of starch-containing bundle sheath cells in warm-season grasses. Crop Sci. 17:529.

Anderson, S. J., T. J. Klopfenstein, and V. A. Wilkerson. 1988. Escape protein supplementation of yearling steers grazing smooth brome pastures. J. Anim. Sci. 66:237.

AOAC. 1990. Official Methods of Analysis (15th Ed.). Association of Official Analytical Chemists, Arlington, VA.

Beever, D. E., and R. C. Siddons. 1986. Digestion and metabolism in the grazing ruminant. In: L. P. Milligan, W. L. Grovum, and A. Dobson (Ed.) Control of Digestion and Metabolism in Ruminants. pp 479-497. Prentice-Hall, Englewood Cliffs, NJ.

Blasi, D. A., J. K. Ward, T. J. Klopfenstein, and R. A. Britton. 1991. Escape protein for beef cows: III. Performance of lactating beef cows grazing smooth brome or big bluestem. J. Anim. Sci. 69: 2294.

Chalupa, W. 1975. Rumen bypass and protection of proteins and amino acids. J. Dairy Sci. 58:1198.

Chen, T. M., W. H. Campbell, P. Dittrich, and C. C. Black. 1973. Distribution of carboxylation and decarboxylation enzymes in isolated mesophyll cells and bundle sheath strands of $\mathrm{C}_{4}$ plants. Biochem. Biophys. Res. Commun. 51:461.

Cotta, M. A., and R. B. Hespell. 1986. Protein and amino acid metabolism of rumen bacteria. In: L. P. Milligan, W. L. Grovum, and A. Dobson (Ed.) Control of Digestion and Metabolism in Ruminants. pp 122-136. Prentice-Hall, Englewood Cliffs, NJ.

Fahrney, D. E., and A. M. Gold. 1963. Sulfonyl fluorides as inhibitors of esterases. I. Rates of reaction with acetylcholinesterase, $\alpha$-chymotrypsin, and trypsin. J. Am. Chem. Soc. 85:997.

Griffin, J. L., and G. A. Jung. 1983. Leaf and stem forage quality of big bluestem and switchgrass. Agron. J. 75:723.

Hafley, J. L., B. E. Anderson, and T. J. Klopfenstein. 1993. Supplementation of growing cattle grazing warm-season grass with proteins of various ruminal degradabilities. J. Anim. Sci. 71: 522.

Huber, S. C., T. C. Hall, and G. E. Edwards. 1976. Differential localization of fraction I protein between chloroplast types. Plant Physiol. (Rockv.) 57:730.

Ku, M. S., M. R. Schmitt, and G. E. Edwards. 1979. Quantitative determination of RuBP carboxylase-oxygenase protein in leaves of several $\mathrm{C}_{3}$ and $\mathrm{C}_{4}$ plants. J. Exp. Bot. 114:89.
Laemmli, U. K. 1970. Cleavage of structural proteins during the assembly of the head of bacteriophage T4. Nature (Lond.) 227: 680.

Mangan, J. L. 1972. Quantitative studies on nitrogen metabolism in the bovine rumen. The rate of proteolysis of casein and ovalbumin and the release and metabolism of the amino acids. Br. J. Nutr. 27:261.

Mathison, G. W., and L. P. Milligan. 1971. Nitrogen metabolism in sheep. Br. J. Nutr. 25:351.

Mertens, D. R. 1977. Dietary fiber components: Relationship to rate and extent of ruminal digestion. Fed. Proc. 36:187.

Mertens, D. R., and L. O. Ely. 1982. Relationship of rate and extent of digestion to forage utilization-A dynamic model evaluation. J. Anim. Sci. 54:895.

Miller, M. S., L. E. Moser, S. S. Waller, and T. J. Klopfenstein. 1993. Switchgrass escape protein as influenced by plant anatomy. Beef Cattle Report. Agric. Res. Div. Univ. of Nebr., MP 59-A.

Minson, D. J., and M. N. McLeod. 1970. The digestibility of temperate and tropical forages. In: M.J.T. Norman (Ed.) Proc. XI Int. Grassl. Cong., April 13-23, 1970, Surfer's Paradise, Queensland, Australia, University of Queensland Press, St. Lucia, Queensland.

Moore, K. J., L. E. Moser, K. P. Vogel, S. S. Waller, B. E. Johnson, and J. F. Pedersen. 1991. Describing and quantifying growth stages of perennial forage grasses. Agron. J. 83:1073.

Mullahey, J. J., S. S. Waller, K. J. Moore, L. E. Moser, and T. J. Klopfenstein. 1992. In situ ruminal protein degradation of switchgrass and smooth bromegrass. Agron. J. 84:183.

Nugent, J.H.A., and J. L. Mangan. 1978. Rumen proteolysis of fraction I leaf protein, casein, and bovine serum albumin. Proc. Nutr. Soc. 37:48 (Abstr.).

Rutner, A. C., and M. D. Lane. 1967. Non identical subunits of ribulose diphosphate carboxylase. Biochem. Biophys. Res. Commun. 28:531.

Salisbury, F. B., and C. W. Ross. 1985. Plant Physiology (3rd Ed.). Wadsworth Publ. Co., Belmont, CA.

Sanderson, M. A., and W. F. Wedin. 1989. Phenological stage and herbage quality relationships in temperate grasses and legumes. Agron. J. 81:864.

SAS. 1985. SAS User's Guide: Statistics (Version 5 Ed.) SAS Inst. Inc., Cary, NC.

Smith, P. K., R. I. Krohn, G. T. Hermanson, A. K. Mallia, F. H. Gartner, M. D. Provenzano, E. K. Fujimoto, N. M. Goeke, B. J. Olson, and D. C. Klenk. 1985. Measurement of protein using bicinchoninic acid. Anal. Biochem. 150:76.

Steel, R.G.D., and J. H. Torrie. 1980. Principles and Procedures of Statistics: A Biometrical Approach (2nd Ed.). McGraw-Hill Book Co., New York.

Storm, E., D. S. Brown, and E. R. Orskov. 1983. The nutritive value of rumen micro-organisms in ruminants. 3. The digestion of microbial amino and nucleic acids in, and losses of endogenous nitrogen from, the small intestine of sheep. Br. J. Nutr. 50:479.

Thornber, J. P., R.P.F. Gregory, C. A. Smith, and J. L. Bailey. 1967. Studies on the nature of the chloroplast lamella. I. Preparation and some properties of two chlorophyll-protein complexes. Biochemistry $6: 391$.

Uedan, K., and T. Sugiyama. 1976. Purification and characterization of phosphoenolpyruvate carboxylase from maize leaves. Plant Physiol. (Rockv.) 57:906.

Van Soest, P. J. 1982. Nutritional Ecology of the Ruminant. O\&B Books, Corvallis, OR.

Waldo, D. R., L. W. Smith, and E. L. Cox. 1972. Model of cellulose disappearance from the rumen. J. Dairy Sci. 55:125.

Wilkerson, V. A., S. M. Hannah, R. C. Cochran, and T. J. Klopfenstein. 1990. Rinsing procedures for in situ protein degradation as influenced by technician and method. J. Anim. Sci. 68(Suppl. 1):517(Abstr.). 